\title{
PENGARUH LEVERAGE TERHADAP MANAJEMEN LABA DENGAN CORPORATE GOVERNANCE SEBAGAI VARIABEL PEMODERASI PADA PERUSAHAAN MANUFAKTUR SEKTOR ANEKA INDUSTRI YANG TERDAFTAR DI BEI PERIODE 2013-2016
}

\author{
Diana Savitri \\ Program Studi Akuntansi Fakultas Ekonomi Universitas Negeri Yogyakarta \\ dianasavitri1@gmail.com \\ Denies Priantinah \\ Staf Pengajar Jurusan Pendidikan Akuntansi Universitas Negeri Yogyakarta \\ denies_priantinah@uny.ac.id
}

\begin{abstract}
Abstrak: Pengaruh Leverage Terhadap Manajemen Laba Dengan Corporate Governance Sebagai Variabel Pemoderasi Pada Perusahaan Manufaktur Sektor Aneka Industri Yang Terdaftar Di Bei Periode 2013-2016 Penelitian ini bertujuan untuk menganalisis: (1) Pengaruh Leverage terhadap Manajemen Laba pada perusahaan manufaktur sektor aneka industri yang terdaftar di BEI periode 2013-2016, (2) Pengaruh Dewan Komisaris Independen, Kepemilikan Institusional, dan Kualitas Auditor sebagai variabel moderasi dalam hubungan antara Leverage terhadap Manajemen Laba. Populasi penelitian adalah perusahaan manufaktur sektor aneka industri yang terdaftar di BEI periode 2013-2016. Penelitian ini menggunakan metode purposive sampling memperoleh data sebanyak 68. Leverage berpengaruh negatif terhadap Manajemen Laba. Dewan Komisaris Independen tidak memoderasi hubungan Leverage terhadap Manajemen Laba. Kepemilikan Institusional tidak memoderasi hubungan Leverage terhadap Manajemen Laba. Kualitas Auditor tidak memoderasi hubungan Leverage terhadap Manajemen Laba.
\end{abstract}

Kata kunci: Manajemen Laba, Leverage, Dewan Komisaris Independen, Kepemilikan Institusional, Kualitas Auditor.

Abstract The Effect Of Leverage On Earnings Management With Corporate Governance As Moderating Variable Various Industries Manufacturing Companies Listed On Indonesia Stock Exchange 2013-2016 This study was aimed to find out: (1) The effect of Leverage on Earnings management. (2) The effect of the Independent Board of Commissioners, Institutional Ownership, and Quality Auditor as a moderating variable in the relationship between Leverage to Earnings Management. The research population is barious industries manufacturing companies listed on IDX 2013-2016. Using a purposive sampling method and obtaining data of 68 the research found that Leverage has a negative influence on Earnings Management. Additionally, the Independent Board of Commissioners does not moderate the relationship of Leverage with Earnings Management. Institutional Ownership does not moderate the relationship of Leverage with Earnings Management. Auditor Quality does not moderate the relationship of Leverage with Earnings Management.

Keywords: Earnings Management, Leverage, Independent Board of Commisioners, Institusional Ownership, Auditor Quality

\section{PENDAHULUAN}

Laporan keuangan merupakan sarana

mengkomunikasikan informasi keuangan kepada pihak-pihak di luar korporasi. Laporan keuangan perusahaan diharapkan dapat memberi informasi bagi calon 


\section{JURNAL NOMINAL / VOLUME VIII NOMOR 2 / TAHUN 2019}

investor dan calon kreditur guna mengambil keputusan yang terkait dengan dana investasi (Setiawati, 2002). Salah satu komponen penting dari laporan keuangan adalah komponen laba. Laba digunakan untuk mengukur kinerja dan peningkatan dari suatu entitas. Informasi laba yang terdapat di laporan keuangan merupakan informasi utama dalam pengambilan keputusan untuk berinvestasi. Sehingga informasi laba sering menjadi target rekayasa melalui praktik pengelolaan laba untuk tujuan tertentu yang dikenal dengan istilah Manajemen Laba (Setiawati, 2002).

Manajemen Laba adalah suatu cara yang ditempuh manajemen dalam mengelola laporan keuangan perusahaan melalui pemilihan kebijakan akuntansi tertentu dengan tujuan meningkatkan laba bersih dan nilai perusahaan sesuai dengan harapan manajemen (Badruzzaman, 2010). Beberapa kasus Manajemen Laba yang terjadi di Indonesia beberapa tahun yang lalu antara lain, kasus praktik Manajemen Laba yang terjadi pada PT. Kimia Farma Tbk, PT. Lippo Tbk, dan perusahaan Indomobil (Boediono, 2005). Tindakan Manajemen Laba terjadi karena pihak menajemen lebih banyak mengetahui informasi internal dan prospek perusahaan di masa yang akan datang dibandingkan dengan pemegang saham. Terkadang pihak manajemen menyampaikan informasi kepada pemegang saham tidak sesuai dengan kondisi perusahaan yang sesungguhnya, sehingga manajemen mendapatkan peluang untuk melakukan praktik Manajemen Laba demi memaksimalkan utilitasnya.

Leverage adalah rasio-rasio yang digunakan untuk mengukur seberapa jauh aktiva perusahaan dibiayai dengan hutang (Riyanto, 1995). Penelitian yang dilakukan oleh Guna \& Herawaty (2010) menunjukkan bahwa Leverage berpengaruh terhadap Manajemen Laba. Hal itu sejalan dengan penelitian yang dilakukan oleh Naftalia (2013) bahwa Leverage berpengaruh terhadap Manajemen Laba. Sedangkan penelitian yang dilakukan oleh Perdana (2012) dan Almadara (2017) menunjukkan bahwa Leverage berpengaruh negatif terhadap Manajemen Laba.

Berdasarkan teori keagenan, tindakan Manajemen Laba dapat diminimalisir dengan mekanisme Corporate Governance. Naftalia (2013) mengungkapkan bahwa mekanisme Corporate Governance merupakan suatu konsep yang diajukan untuk meningkatkan kinerja perusahaan melalui pengawasan kinerja manajemen dan menjamin akuntabilitas manajemen terhadap pemegang saham dengan mendasarkan pada kerangka peraturan. Penelitian ini menggunakan 3 komponen mekanisme Corporate Governance yang diharapkan mampu mengontrol tindakan 
Manajemen Laba. Komponen-komponen tersebut yaitu Dewan Komisaris Independen, Kepemilikan Institusional, dan Kualitas Auditor.

Midiastuty \& Machfoedz (2003) menyatakan bahwa perusahaan yang memiliki komposisi anggota dewan komisaris yang berasal dari luar perusahaan dapat mempengaruhi tindakan Manajemen Laba. Penelitian yang dilakukan oleh Guna \& Herawaty (2010) menunjukkan bahwa Komisaris Independen memiliki pengaruh terhadap Manajemen Laba. Penelitian yang dilakukan oleh Naftalia (2013) bahwa komisaris independen tidak terbukti menjadi variabel pemoderasi antara hubungan Leverage terhadap Manajemen Laba. Penelitian yang dilakukan oleh Almadara (2017) menunjukkan bahwa Dewan Komisaris Independen memperkuat pengaruh Leverage terhadap Manajemen Laba.

Penelitian yang dilakukan oleh Naftalia (2013) menunjukkan bahwa Kepemilikan Institusional menjadi variabel pemoderasi antara hubungan Leverage dengan Manajemen Laba. Hasil penelitian tersebut tidak sesuai dengan penelitian yang dilakukan oleh Asy’ari (2016) yang menunjukkan bahwa Kepemilikan Institusional tidak dapat menjadi variabel pemoderasi antara hubungan Leverage dengan Manajemen Laba. Hasil penelitian yang dilakukan oleh Siregar \& Utama
(2005) menunjukkan bahwa Kepemilikan Institusional tidak berpengaruh terhadap Manajemen Laba. Hal itu sejalan dengan penelitian yang dilakukan oleh Guna \& Herawaty (2010) dan Naftalia (2013).

Hasil penelitian Almadara (2017) menunjukkan bahwa Kualitas Auditor mampu mengurangi tindakan Manajemen Laba. Sedangkan penelitian yang dilakukan oleh Luhgiatno (2017) dan Christiani \& Nugrahanti (2014) menunjukkan bahwa Kualitas Auditor tidak berpengaruh terhadap Manajemen Laba.

Meskipun hasil penelitian-penelitian di atas tidak konsisten untuk variabel Corporate Governance yang diproksikan dengan Dewan Komisaris Independen, Kepemilikan Institusional, dan Kualitas Auditor tetapi penelitian tersebut dapat menunjukkan pentingnya penerapan Good Corporate Governance dalam suatu perusahaan. Berdasarkan paparan latar belakang masalah yang telah diuraikan dan beberapa hasil penelitian sebelumnya yang menunjukkan hasil yang berbeda-beda, peneliti tertarik melakukan penelitian dengan judul: "Pengaruh Leverage Terhadap Manajemen Laba dengan Corporate Governance Sebagai Variabel Pemoderasi".

\section{KAJIAN LITERATUR}

Perspektif hubungan keagenan menjadi dasar yang digunakan untuk 
memahami hubungan antara manajer dan pemegang saham. Jensen \& Meckling (1976) mengungkapkan bahwa hubungan keagenan merupakan kontrak antara manajer (agen) dengan pemegang saham (prinsipal). Hubungan antara agen dengan prinsipal seringkali menimbulkan konflik. Konflik tersebut terjadi karena agen dengan prinsipal memiliki tujuan yang berbeda dan masing-masing menginginkan agar tujuan mereka terpenuhi. Agen menginginkan kepentingannya diakomodasi dengan pemberian kompensasi yang sebesarbesarnya atas kinerjanya dalam menjalankan perusahaan, sedangkan prinsipal menginginkan pengembalian yang lebih besar atas investasi yang mereka tanamkan.

Agen dengan prinsipal memiliki perbedaan informasi mengenai kondisi perusahaan. Agen memiliki informasi yang lebih lengkap daripada prinsipal. Keadaan ini dikenal sebagai asimetri informasi. Richardson (1998) mengungkapkan bahwa asimetri informasi antara agen dengan prinsipal memberikan kesempatan kepada agen untuk melakukan Manajemen Laba. Sehingga agen seringkali melakukan manipulasi ketika melaporkan kondisi perusahaan kepada prinsipal. Agen melakukan manipulasi dengan tujuan untuk mendapatkan kompensasi yang diinginkan.
Sartono (2014) mengungkapkan bahwa financial Leverage menunjukan proporsi atas penggunaan hutang untuk membiayai investasinya. Semakin besar rasio Leverage berarti semakin tinggi hutang perusahaan. Firth \& Smith (1992) menyatakan bahwa semakin besar hutang yang dimiliki oleh perusahaan maka pengawasan yang dilakukan oleh kreditor akan semakin ketat. Hal tersebut mengakibatkan fleksibelitas manajemen untuk melakukan Manajemen Laba semakin berkurang. Hal ini berarti bahwa semakin tinggi rasio Leverage maka semakin rendah kemungkinan pihak manajemen untuk melakukan Manajemen Laba. Almadara (2017) dalam penelitiannya mengungkapkan bahwa variabel Leverage berpengaruh negatif terhadap Manajemen Laba. Hal ini selaras dengan penelitian yang dilakukan oleh Mahiswari \& Nugroho (2014).

H1: Leverage berpengaruh negatif terhadap Manajemen Laba.

Dewan Komisaris Independen merupakan komisaris yang tidak terafiliasi dengan direksi, anggota dewan komisaris lainnya dan pemegang saham pengendali, serta bebas dari hubungan bisnis atau hubungan lainnya yang dapat mempengaruhi kemampuannya untuk bertindak independen. Rahmawati (2013) mengungkapkan dalam penelitiannya bahwa Komisaris Independen berpengaruh 


\section{JURNAL NOMINAL / VOLUME VIII NOMOR 2 / TAHUN 2019}

signifikan negatif karena Dewan Komisaris Independen berperan melakukan fungsi pengawasan terhadap operasional perusahaan yang dilakukan oleh pihak manajemen. Hal tersebut telah memberikan kontribusi yang efektif terhadap hasil dari proses penyusunan laporan keuangan yang berkualitas, sehingga Dewan Komisaris Independen membatasi tindakan Manajemen Laba yang dilakukan manajemen. Proporsi Dewan Komisaris Independen pada suatu perusahaan akan memperkuat pengaruh Leverage terhadap Manajemen Laba. Hal ini sesuai dengan hasil penelitian yang dilakukan Almadara (2017).

H2: Dewan Komisaris Independen sebagai variabel moderasi memperkuat hubungan antara Leverage terhadap Manajemen Laba.

Kepemilikan Institusional yaitu kepemilikan saham perusahaan oleh institusi keuangan seperti perusahaan asuransi, bank, dana pensiun, dan investment banking. Keberadaan Kepemilikan Institusional diharapkan mampu mengurangi tindakan manajemen yang menyimpang. Keberadaan investor institusional dianggap mampu menjalankan mekanisme monitoring yang efektif dalam setiap keputusan yang diambil oleh manajer. Hasil penelitian yang dilakukan Naftalia (2013) menunjukkan bahwa Kepemilikan Institusional memoderasi hubungan antara Leverage dengan
Manajemen Laba. Naftalia (2013) menyatakan bahwa Kepemilikan Institusional yang tinggi dapat membatasi tindakan pengelolaan laba (earnings management) yang dilakukan oleh manajer. Sehingga dengan adanya Kepemilikan Institusional, investor institusional dapat melakukan kontrol terhadap tindakan manajer terkait Leverage sehingga dapat meminimalisir tindakan Manajemen Laba. Kepemilikan Institusional akan memperkuat hubungan antara Leverage terhadap Manajemen Laba.

H3: Kepemilikan Institusional sebagai variabel moderasi memperkuat hubungan antara Leverage terhadap Manajemen Laba.

Audit laporan keuangan dilakukan untuk menghasilkan laporan keuangan yang berkualitas. Laporan keuangan yang berkualitas, relevan, dan reliabilitas dihasilkan dari audit yang dilakukan oleh auditor berkualitas tinggi. Laporan keuangan yang diaudit oleh auditor berkualitas tinggi dipercaya oleh pemakai laporan keuangan karena auditor berkuaitas tinggi lebih teliti dalam melakukan audit laporan keuangan. Hasil penelitian yang dilakukan oleh Herawaty (2008) menunjukkan bahwa tingkat kepercayaan pemakai informasi yang diaudit terutama pihak eksternal perusahaan dipengaruhi oleh kualitas audit dari auditor. Penggunaan jasa auditor yang berasal dari KAP dengan kualitas tinggi yaitu KAP Big 


\section{JURNAL NOMINAL / VOLUME VIII NOMOR 2 / TAHUN 2019}

4 dapat meningkatkan kepercayaan pihak eksternal karena perusahaan yang diaudit oleh KAP Big 4 kualitas auditnya tinggi sedangkan jika diaudit oleh KAP Non Big 4 maka kualitas auditnya rendah. Sehingga perusahaan yang diaudit oleh KAP Non Big 4 cenderung lebih tinggi dalam melakukan anajemen laba. Sehingga Kualitas Auditor dapat memperkuat pengaruh Leverage terhadap Manajemen Laba. Hal ini sesuai dengan hasil penelitian yang dilakukan Almadara (2017).

H4: Kualitas Auditor sebagai variabel moderasi memperkuat pengaruh Leverage terhadap Manajemen Laba.

\section{METODE PENELITIAN}

\section{Jenis Penelitian}

Penelitian ini merupakan penelitian yang memiliki hubungan kausal. Metode penelitian yang digunakan adalah metode kuantitatif. Menurut Sugiyono (2016:7), penelitian kuantitatif merupakan penelitian yang datanya berupa angka-angka dan dianalisis menggunakan statistik.

\section{Tempat dan Waktu Penelitian}

Penelitian ini dilakukan dengan mengambil data sekunder perusahaan yang terdaftar di Bursa Efek Indonesia. Data yang digunakan diperoleh dari website resmi Bursa Efek Indonesia www.idx.co.id dan www.sahamok.com. Pengumpulan dan pengolahan data akan dilaksanakan bulan Februari 2019 hingga bulan Maret 2019.

\section{Subjek Penelitian}

Populasi dalam penelitian ini adalah perusahaan manufaktur sektor aneka industri yang terdaftar di Bursa Efek Indonesia periode tahun 2013-2016. Penelitian menggunakan metode purposive sampling,. Berikut kriteria sampel penelitian:

a. Perusahaan manufaktur sektor aneka industri yang terdaftar di Bursa Efek Indonesia pada tahun 2013-2016.

b. Perusahaan menerbitkan laporan keuangan dalam satuan mata uang rupiah selama periode penelitian yaitu 2013-2016.

c. Perusahaan menyajikan data secara lengkap terkait dengan variabel Leverage, Manajemen Laba, Dewan Komisaris Independen, Kepemilikan Institusional, dan Kualitas Auditor selama periode penelitian yaitu 2013-2016.

\section{Definisi Operasional Variabel \\ a. Manajemen Laba}

Manajemen Laba diukur dengan proksi discretionary accruals. Dalam penelitian ini discretionary accruals dihitung menggunakan model Jones yang dimodifikasi. Rumus perhitungan discretionary accruals yaitu:

1) Total accruals dengan menggunakan model Jones yang dimodifikasi

$\mathrm{TAC}=\mathrm{NI}_{\mathrm{it}}-\mathrm{CFi}_{\mathrm{t}}$

2) Total accruals yang diestimasi dengan persamaan regresi OLS (Ordinary Least Square)

$\mathrm{TAC}_{\mathrm{t}} / \mathrm{TA}_{\mathrm{t}-1} \quad=\quad \beta_{1}\left(1 / \mathrm{TA}_{\mathrm{t}-1}\right) \quad+$ $\beta_{2}\left[\left(\Delta \mathrm{REV}_{\mathrm{t}}-\Delta \mathrm{REC}_{\mathrm{t}}\right) / \mathrm{TA}_{\mathrm{t}-1}\right] \quad+$ $\beta_{3}\left(\mathrm{PPE}_{\mathrm{t}} / \mathrm{TA}_{\mathrm{t}-1}\right)+\varepsilon$ 
3) Non Accruals Diskretioner
NDTAC $_{t} \quad=\quad \beta_{1}\left(1 / \mathrm{TA}_{\mathrm{t}-1}\right)$
$\beta_{2}\left[\left(\Delta \mathrm{REV}_{\mathrm{t}}-\Delta \mathrm{REC}_{\mathrm{t}}\right) / \mathrm{TA}_{\mathrm{t}-1}\right]$
$\beta_{3}\left(\mathrm{PPE}_{\mathrm{t}} / \mathrm{TA}_{\mathrm{t}-1}\right)+\varepsilon$
4) Diskresioner Total Akrual
DTAC $_{t}=$ TACt $/ \mathrm{TA}_{\mathrm{t}-1}-\mathrm{NDTAC}_{\mathrm{t}}$

Keterangan:

TAC: Total accruals

$\mathrm{NI}_{\mathrm{it}}$ : laba bersih (net income) perusahaan $\mathrm{i}$ pada periode $t$

$\mathrm{CF}_{\mathrm{it}}$ : arus kas operasi (cash flow of operation) perusahaan i pada periode $\mathrm{t}$

TAC $_{\mathrm{t}}$ : total accruals pada periode $\mathrm{t}$

$\mathrm{TA}_{\mathrm{t}-1}$ : total aset periode $\mathrm{t}-1$

$\triangle \mathrm{REV}_{\mathrm{t}}$ : perubahan pendapatan dalam periode $\mathrm{t}$

$\triangle \mathrm{REC}_{\mathrm{t}}$ : perubahan piutang usaha dalam periode $\mathrm{t}$

$\mathrm{PPE}_{\mathrm{t}}$ : property, plan, and equipment periode $\mathrm{t}$

$\beta_{1}, \beta_{2}, \beta_{3}$ : koefisiensi regresi

$\varepsilon$ : error term (Galat)

NDTAC $t_{t}$ non akrual diskresioner pada tahun $\mathrm{t}$

DTAC $_{\mathrm{t}}$ : diskresioner total akrual tahun $\mathrm{t}$

\section{b. Leverage}

Leverage yaitu perbandingan antara total aktiva dengan total kewajiban yang di miliki perusahaan. Dalam penelitian ini, rasio Leverage diukur dengan debt ratio.

\section{$\frac{\text { Total Utang }}{\text { Total Aset }}$}

\section{c. Dewan Komisaris Independen}

Dewan Komisaris Independen adalah anggota dewan komisaris yang tidak terafiliasi dengan manajemen, anggota dewan komisaris lainnya dan pemegang saham pengendali, serta bebas dari hubungan bisnis atau hubungan lainnya yang dapat mempengaruhi kemampuannya untuk bertindak independen atau bertindak demi kepentingan perusahaan. Dewan
Komisaris Independen dihitung dengan rumus:

$$
\frac{\sum \text { Komisaris Independen }}{\sum \text { Dewan Komisaris }} X 100 \%
$$

\section{d. Kepemilikan Institusional}

Kepemilikan Institusional adalah kepemilikan saham perusahaan oleh institusi keuangan seperti perusahaan asuransi, bank, dana pensiun, dan investment banking (Siregar \& Utama: 2005). Kepemilikan institusonal dihitung dengan rumus:

$$
\frac{\sum \text { Saham Institusi }}{\sum \text { Saham Beredar }} X 100 \%
$$

\section{e. Kualitas Auditor}

Variabel Kualitas Auditor (KA) diukur dengan data non metrik (ordinal), jika diaudit oleh KAP Big 4 maka diberikan nilai 1 dan jika diaudit oleh KAP Non Big 4 diberikan nilai 0 (Herawaty, 2008).

\section{Teknik Pengumpulan Data}

Dalam penelitian ini data yang digunakan merupakan data sekunder yang bersifat kuantitatif. Data sekunder dapat berupa berupa bukti, catatan atau laporan historis. Teknik pengumpulan data yang digunakan adalah metode dokumentasi untuk mengumpulkan annual report.

\section{Teknik Analisis Data}

Teknik analisis data dalam penelitian ini menggunakan uji statistik deskriptif; uji asumsi klasik (uji normalitas, uji multikolinearitas, uji heteroskedastisitas, uji autokorelasi), dan uji hipotesis (regresi linear sederhana dan MRA). 


\section{HASIL PENELITIAN DAN \\ PEMBAHASAN}

1. Deskripsi Data Penelitian

Penelitian ini menggunakan data sekunder berupa laporan keuangan auditan dan data keuangan lainnya yang diperoleh ww.idx.co.id dan www.sahamok.com. Sampel yang dipilih menggunakan teknik purposive sampling sejumlah 68 berasal dari 17 perusahaan manufaktur sektor aneka industri yang terdaftar di BEI tahun 2013-2016.

\section{Analisis Statistik Deskriptif}

Analisis statistik deskriptif pada penelitian ini digunakan untuk memberikan gambaran suatu data pada variabel yang digunakan.

Tabel 1. Hasil Analisis Statistik Deskriptif

\begin{tabular}{|c|c|c|c|c|c|}
\hline & $\mathbf{N}$ & $\stackrel{\Xi}{\Sigma}$ & $\sum^{\tilde{E}}$ & $\sum_{\Sigma}^{\bar{E}}$ & $\begin{array}{l}\text { Std. } \\
\text { Devi } \\
\text { ation }\end{array}$ \\
\hline EM & 68 & $-0,40$ & 0,28 & 0,05 & 0,14 \\
\hline LEV & 68 & 0,17 & 3,03 & 0,60 & 0,55 \\
\hline KI & 68 & 0,20 & 0,67 & 0,38 & 0,09 \\
\hline INST & 68 & 0,35 & 0,90 & 0,68 & 0,17 \\
\hline KA & 68 & 0,00 & 1,00 & 0,35 & 0,48 \\
\hline $\begin{array}{l}\text { Valid } \\
\mathrm{N}\end{array}$ & 68 & & & & \\
\hline
\end{tabular}

Sumber: hasil olah data sekunder

Tabel 1 menunjukkan nilai rata-rata,

nilai maksimum, nilai minimum dan standar deviasi dari masing-masing variabel yaitu:

a. Analisis deskriptif dari Manajemen Laba adalah memiliki minimum $-0,40$, nilai maksimum sebesar 0,28 , nilai mean sebesar 0,05 dan standar deviasi sebesar 0,14.

b. Analisis deskriptif dari Leverage adalah memiliki nilai minimum 0,17 , nilai maksimum sebesar 3,03, nilai mean sebesar 0,60, dan standar deviasi sebesar 0,55.

c. Analisis deskriptif dari Dewan Komisaris Independen adalah memiliki nilai minimum 0,20 , nilai maksimum sebesar 0,67 , nilai mean sebesar 0,38 , dan standar deviasi sebesar 0,09.

d. Analisis deskriptif dari Kepemilikan Institusional adalah memiliki nilai minimum 0,35 , nilai maksimum sebesar 0,90 , nilai mean sebesar 0,68 , dan standar deviasi sebesar 0,17.

e. Analisis deskriptif dari Kualitas Auditor adalah memiliki nilai minimum 0,00 , nilai maksimum 1 , nilai mean 0,35 , dan standar deviasi 0,48 .

3. Hasil Uji Hipotesis

a. Analisis Regresi Linier Sederhana

\section{Pengujian Hipotesis 1}

Tabel 2. Hasil Analisis Regresi Linier Sederhana - Model 1

\begin{tabular}{|c|c|c|c|c|c|}
\hline $\begin{array}{c}\text { Const } \\
\text { anta }\end{array}$ & $\begin{array}{c}\text { Unstanda } \\
\text { rdized } \\
\text { Coefficie } \\
\text { nts }\end{array}$ & $\mathbf{R}^{2}$ & $\begin{array}{c}\text { Sig. } \\
\text { F }\end{array}$ & $\mathbf{t}$ & $\begin{array}{c}\text { Sig } \\
. t\end{array}$ \\
\hline 0,126 & $-0,133$ & $\begin{array}{r}0 \\
27 \\
0\end{array}$ & $\begin{array}{l}0,0 \\
00^{\mathrm{b}}\end{array}$ & $\begin{array}{r}- \\
4, \\
93 \\
7\end{array}$ & $\begin{array}{r}0, \\
00 \\
0\end{array}$ \\
\hline
\end{tabular}

Sumber: hasil olah data sekunder

Nilai koefisien determinasi (R square)

sebesar 0,270 menunjukkan bahwa Manajemen Laba dapat dijelaskan oleh Leverage sebesar $27 \%$ sedangkan sisanya sebesar 73\% dijelaskan oleh variabel lain diluar model penelitian. Dari tabel ANOVA dapat diketahui nilai probabilitas F sebesar 0,000 lebih kecil dari $\alpha$ yang digunakan 
yaitu 0,05 yang berarti signifikan.

Berdasarkan hasil perhitungan, nilai probabilitas $\mathrm{t}$ sebesar 0,000 lebih kecil dari 0,05 yang berarti variabel Leverage berpengaruh terhadap Manajemen Laba. - $\mathrm{t}$ hitung $<-t$ tabel $(-4,937<-1,668)$. Koefisien regresi Leverage sebesar $-0,133$ menunjukkan bahwa terdapat hubungan negatif antara Leverage dengan Manajemen Laba, jadi ketika Leverage tinggi maka akan menurunkan Manajemen Laba. Sehingga $\mathbf{H}_{0}$ Ditolak yaitu mendukung hipotesis pertama yang menyatakan bahwa Leverage berpengaruh negatif terhadap Manajemen Laba.

b. Hasil Uji MRA

Pengujian Hipotesis 2

Tabel 3. Hasil Analisis MRA - Model 2

\begin{tabular}{lcccc}
\hline Variabel & $\mathbf{R}^{2}$ & Sig.F & $\mathbf{t}$ & Sig.t \\
\hline LEV & 0,294 & 0,000 & $-0,019$ & 0,985 \\
KI & & & $-0,685$ & 0,496 \\
Lev*KI & & & $-0,437$ & 0,664 \\
(modera & & & & \\
t1) & & & & \\
\hline
\end{tabular}

Sumber: hasil olah data sekunder

Nilai koefisien determinasi (R square) sebesar 0,294 menunjukkan bahwa Manajemen Laba dapat dijelaskan oleh interaksi variabel moderasi $\mathrm{LEV}^{*} \mathrm{KI}$ sebesar $29,4 \%$ sedangkan sisanya sebesar $71,6 \%$ dijelaskan oleh variabel di luar model penelitian. Dari tabel tersebut menunjukkan nilai probabilitas $\mathrm{F}$ sebesar 0,000 dengan nilai signifikansi sebesar 0,05 yang berarti signifikan. Hasil uji $\mathrm{t}$ menunjukkan bahwa nilai probabilitas sebesar 0,664 lebih besar dari nilai signifikansi seebesar 0,05 yang berarti bahwa variabel Leverage yang telah dimoderasi oleh Dewan Komisaris Independen tidak mempengaruhi Manajemen Laba. $-\mathrm{t}$ tabel $\leq \mathrm{t}$ hitung $\leq \mathrm{t}$ tabel $(-1,668 \leq-0,437 \leq 1,668)$. Sehingga Ho Diterima yaitu hasil tidak mendukung hipotesis ketiga yang menyatakan bahwa Dewan Komisaris Independen sebagai variabel moderasi memperkuat hubungan antara Leverage terhadap Manajemen Laba.

\section{Pengujian Hipotesis 3}

Tabel 4. Hasil Analisis MRA - Model 3

\begin{tabular}{lcccc}
\hline Variabel & $\mathbf{R}^{2}$ & Sig.F & t & Sig.t \\
\hline LEV & 0,292 & 0,000 & $-1,871$ & 0,066 \\
INST & & & $-1,282$ & 0,204 \\
LEV*IN & & & 1,409 & 0,164 \\
ST & & & & \\
(modera & & & & \\
t2) & & & & \\
\hline
\end{tabular}

Sumber: hasil olah data sekunder

Nilai koefisien determinasi (R square) sebesar 0,292 menunjukkan bahwa Manajemen Laba dapat dijelaskan oleh interaksi variabel moderasi LEV*INST sebesar 29,2\% sedangkan sisanya sebesar $70,2 \%$ dijelaskan oleh variabel di luar model penelitian. Hasil uji F menunjukkan nilai probabilitas $\mathrm{F}$ sebesar 0,000 dengan nilai signifikansi sebesar 0,05 yang berarti signifikan. Hasil uji t menunjukkan bahwa nilai probabilitas sebesar 0,164 lebih besar dari nilai signifikansi seebesar 0,05 yang berarti bahwa variabel Leverage yang telah dimoderasi oleh Kepemilikan Institusional tidak mempengaruhi Manajemen Laba. $-\mathrm{t}$ tabel $\leq \mathrm{t}$ hitung $\leq \mathrm{t}$ tabel $(-1,668 \leq 1,409 \leq$ 
1,668). Sehingga $\mathbf{H}_{0}$ Diterima yaitu hasil tidak mendukung hipotesis ketiga yang menyatakan bahwa Kepemilikan Institusional sebagai variabel moderasi memperkuat hubungan antara Leverage terhadap Manajemen Laba.

\section{Pengujian Hipotesis 4}

Tabel 5. Hasil Analisis MRA - Model 4

\begin{tabular}{lccrr}
\hline Variabel & $\mathbf{R}^{2}$ & Sig.F & $\mathbf{t}$ & Sig.t \\
\hline LEV & 0,275 & 0,000 & $-4,868$ & 0,000 \\
KA & & & $-0,568$ & 0,572 \\
LEV*KA & & & 0,345 & 0,731 \\
(moderat3) & & & & \\
\hline Sumber: hasi
\end{tabular}

Sumber: hasil olah data sekunder

Nilai koefisien determinasi (R square) sebesar 0,275 menunjukkan bahwa Manajemen Laba dapat dijelaskan oleh interaksi variabel moderasi $\mathrm{LEV}^{*} \mathrm{KA}$ sebesar $27,5 \%$ sedangkan sisanya sebesar $72,5 \%$ dijelaskan oleh variabel di luar model penelitian. Hasil uji F menunjukkan nilai probabilitas $\mathrm{F}$ sebesar 0,000 dengan nilai signifikansi sebesar 0,05 yang berarti signifikan. Hasil uji t menunjukkan bahwa nilai probabilitas sebesar 0,731 lebih besar dari nilai signifikansi seebesar 0,05 yang berarti bahwa variabel Leverage yang telah dimoderasi oleh Kualitas Auditor tidak mempengaruhi Manajemen Laba. F hitung $>$ F tabel $(8,106>3,98)$. $-\mathrm{t}$ tabel $\leq \mathrm{t}$ hitung $\leq \mathrm{t}$ tabel $(-1,668 \leq 0,345 \leq 1,668)$. Sehingga Ho Diterima yaitu hasil tidak mendukung hipotesis keempat yang menyatakan bahwa Kualitas Auditor sebagai variabel moderasi memperkuat hubungan antara Leverage terhadap Manajemen Laba.

\section{Pembahasan}

a. Pembahasan Hipotesi Pertama

Hasil uji hipotesis 1 menunjukkan bahwa Leverage berpengaruh negatif terhadap Manajemen Laba pada perusahaan manufaktur sektor aneka industri yang terdaftar di BEI periode 2013 - 2016. Hal ini dibuktikan dengan koefisien regresi yang menunjukkan nilai negatif yaitu 0,133 dan nilai probabilitas sebesar 0,000 lebih kecil dari 0,05. Hasil pengujian tersebut sesuai dengan hipotesis penelitian yang menyatakan bahwa Leverage berpengaruh negatif terhadap Manajemen Laba. hasil penelitian ini sesuai dengan penelitian yang dilakukan oleh Guna \& Herawaty (2010), Perdana (2012), Mahiswari \& Nugroho (2014), dan Almadara (2017) yang menyatakan bahwa variabel Leverage berpengaruh negatif terhadap manajamen laba.

Hasil penelitian tersebut mengindikasikan bahwa tingginya Leverage suatu perusahaan yang ditandai dengan tingginya tingkat hutang mengakibatkan pihak manajemen menjadi lebih sulit untuk memprediksi masa depan perusahaan. Kreditor akan melakukan pengawasan yang lebih ketat ketika perusahaan memiliki hutang yang tinggi. Hal tersebut mengakibatkan berkurangnya fleksibelitas pihak manajemen untuk melakukan Manajemen Laba. Sehingga semakin tinggi Leverage maka Manajemen 
Laba yang dilakukan pihak manajemen akan semakin rendah. Begitu juga sebaliknya, ketika Leverage rendah maka Manajemen Laba yang dilakukan oleh pihak manajemen akan semakin tinggi.

\section{b. Pembahasan Hipotesis Kedua}

Hasil uji hipotesis 2 menunjukkan bahwa Dewan Komisaris Independen tidak memoderasi hubungan Leverage terhadap Manajemen Laba pada perusahaan manufaktur sektor aneka industri yang terdaftar di BEI periode 2013 - 2016. Hal tersebut dibuktikan dengan koefisien regresi interaksi LEV*DKI yang menunjukkan nilai negatif yaitu $-0,145$ dan nilai probabilitas 0,664 lebih besar dari nilai 0,05 . Hasil pengujian tersebut tidak sesuai dengan hipotesis penelitian yang menyatakan bahwa Dewan Komisaris Independen memperkuat hubungan Leverage terhadap Manajemen Laba. Sehingga ketika Leverage rendah dan tindakan Manajemen Laba yang dilakukan oleh pihak manajemen tinggi, maka tindakan tersebut tidak dapat diminimalkan oleh adanya Dewan Komisaris Independen. Hasil penelitian ini sesuai dengan penelitian yang dilakukan oleh Naftalia (2013) serta Juniarta \& Sujana (2015) yang menyatakan bahwa Dewan Komisaris Independen tidak memoderasi hubungan Leverage terhadap Manajemen Laba.

Peran Dewan Komisaris Independen tidak mampu mempengaruhi tindakan
Manajemen Laba yang dilakukan oleh pihak manajemen. Hal tersebut karena pengangkatan Dewan Komisaris Independen hanya untuk pemenuhan regulasi. Fungsi pengawasan operasional yang dilaksanakan oleh Dewan Komisaris Independen tidak berjalan dengan baik. Boediono (2005) mengungkapkan bahwa berdasarkan hasil survei Asian Development Bank, dewan komisaris menjadi tidak independen karena kuatnya kendali dari pendiri perusahaan dan pemegang saham mayoritas yang mengakibatkan fungsi pengawasan yang dilakukan oleh dewan komisaris tidak efektif. Perusahaan melakukan pengangkatan Dewan Komisaris Independen mungkin hanya untuk pemenuhan regulasi tetapi tidak untuk menegakkan good coporate governance (Siregar \& Utama, 2005).

\section{c. Pembahasan Hipotesis Ketiga}

Hasil uji hipotesis 3 menunjukkan bahwa Kepemilikan Institusional tidak memoderasi hubungan Leverage terhadap Manajemen Laba pada perusahaan manufaktur sektor aneka industri yang terdaftar di BEI periode 2013-2016. Hal ini dibuktikan dengan koefisien regresi yang menunjukkan nilai positif yaitu 0,465 dan nilai probabilitas sebesar 0,164 lebih besar dari 0,05 . Hasil pengujian tersebut tidak sesuai dengan hipotesis penelitian yang menyatakan bahwa Kepemilikan 


\section{JURNAL NOMINAL / VOLUME VIII NOMOR 2 / TAHUN 2019}

Institusional memperkuat hubungan Leverage terhadap Manajemen Laba. Sehingga ketika Leverage rendah dan tindakan Manajemen Laba yang dilakukan oleh pihak manajemen tinggi, maka tindakan tersebut tidak dapat diminimalkan oleh adanya Kepemilikan Institusional.

Kepemilikan Institusional tidak mampu mempengaruhi tindakan Manajemen Laba yang dilakukan oleh pihak manajemen. Pihak manajemen tetap melakukan tindakan Manajemen Laba meskipun terdapat pemilik institusional, karena pemilik institusional tidak fokus pada urusan Leverage, tetapi pada current earnings. Hasil penelitian tersebut sesuai dengan penelitian yang dilakukan oleh Asy'ari (2016) yang menunjukkan bahwa Kepemilikan Institusional tidak memoderasi hubungan Leverage dengan Manajemen Laba. Porter (1992) dalam Midiastuty \& Machfoedz (2003) menjelaskan bahwa Kepemilikan Institusional adalah pemilik yang fokus pada current earnings. Ketika pemilik institusional fokus pada current earnings sementara Leverage fokus pada jangka panjang, maka manajer tetap melakukan Manajemen Laba untuk meningkatkan laba jangka pendek. Kepemilikan Institusional tidak fokus terhadap keputusan manajemen terkait tingginya Leverage yang dapat menurunkan Manajemen Laba. Sehingga adanya Kepemilikan Institusional tidak mampu memperkuat pengaruh Leverage terhadap Manajemen Laba.

\section{d. Pembahasan Hipotesis Keempat}

Hasil uji hipotesis 4 menunjukkan bahwa Kualitas Auditor tidak memoderasi hubungan Leverage terhadap Manajemen Laba pada perusahaan manufaktur sektor aneka industri yang terdaftar di BEI periode 2013 - 2016. Hal ini dibuktikan dengan koefisien regresi yang menunjukkan nilai positif yaitu 0,058 dan nilai probabilitas sebesar 0,731 lebih besar dari 0,05. Hasil pengujian tersebut tidak sesuai dengan hipotesis penelitian yang menyatakan bahwa Kualitas Auditor memperkuat hubungan Leverage terhadap Manajemen Laba. Sehingga ketika Leverage rendah dan tindakan Manajemen Laba yang dilakukan oleh pihak manajemen tinggi, maka tindakan tersebut tidak dapat diminimalkan oleh Kualitas Auditor dalam suatu perusahaan.

Kualitas Auditor dalam suatu perusahaan tidak mempengaruhi tindakan Manajemen Laba yang dilakukan oleh pihak manajemen. Dengan mengabaikan peran KAP Big 4, pihak manajemen tetap melakukan Manajemen Laba ketika Leverage rendah. Hasil penelitian ini didukung penelitian yang dilakukan oleh Luhgiatno (2010) dan Christiani \& Nugrahanti (2014). Masyarakat beranggapan bahwa perusahaan yang diaudit oleh KAP Big 4 kualitas auditnya 
tinggi sedangkan jika diaudit oleh KAP Non Big 4 maka kualitas auditnya rendah. Sehingga perusahaan yang diaudit oleh KAP Non Big 4 cenderung lebih tinggi dalam melakukan Manajemen Laba. Namun anggapan tersebut kurang tepat, karena pada kenyataannya perusahaan yang diaudit oleh KAP Big 4 tidak mampu mengurangi tindakan Manajemen Laba yang dilakukan oleh pihak manajemen. Luhgiatno (2010) mengungkapkan bahwa perusahaan memiliki keinginan agar laporan keuangan terlihat bagus tetapi mengabaikan keberadaan KAP Big 4. Sehingga Kualitas Auditor tidak mampu memperkuat pengaruh Leverage terhadap Manajemen Laba.

\section{SIMPULAN DAN SARAN}

\section{Simpulan}

Berdasarkan hasil penenlitian yang telah dilakukan, maka dapat ditarik kesimpulan sebagai berikut:

a. Leverage berpengaruh negatif terhadap Manajemen Laba pada perusahaan manufaktur sektor aneka industri yang terdaftar di BEI tahun 2013-2016.

b. Dewan Komisaris Independen tidak berpengaruh terhadap hubungan Leverage dengan Manajemen Laba pada perusahaan manufaktur sektor aneka industri yang terdaftar di BEI tahun 20132016.

c. Kepemilikan Institusional tidak berpengaruh terhadap hubungan Leverage dengan Manajemen Laba pada perusahaan manufaktur sektor aneka industri yang terdaftar di BEI tahun 2013-2016.

d. Kualitas Auditor tidak berpengaruh terhadap hubungan Leverage dengan Manajemen Laba pada perusahaan manufaktur sektor aneka industri yang terdaftar di BEI tahun 2013-2016.

\section{Saran}

Terdapat beberapa saran yang dapat peneliti sampaikan berdasarkan penelitian yang telah dilakukan yaitu:
a.
Bagi Perusahaan

Perusahaan sebaiknya tetap menerapkan mekanisme Good Corporate Governance dalam perusahaan meskipun dalam penelitian ini Corporate Governance tidak terbukti mempengaruhi tindakan Manajemen Laba.

b. Bagi Pengguna Laporan Keuangan

Pemakai laporan keuangan sebaiknya lebih cermat ketika membaca laporan keuangan, mengingat terdapat beberapa kasus Manajemen Laba yang terjadi di Indonesia. c. Bagi Penelitian Selanjutnya

1) Penulis hanya menggunakan empat tahun periode penelitian, pada penelitian selanjutnya disarankan untuk mena mbah periode penelitian agar hasil penelitian lebih dapat menggambarkan keadaan yang sebenarnya.

2) Penelitian ini hanya menggunakan 68 sampel yang diperoleh dari 17 
perusahaan manufaktur sektor aneka industri selama empat tahun. Pada penelitian selanjutnya diharapkan peneliti dapat memperluas populasi penelitian dan menambah jumlah sampel agar hasil penelitian dapat mewakili dan menunjukkan keadaan yang sebenarnya.

3) Penelitian ini hanya menggunakan 5 variabel penelitian, penelitian selanjutnya dapat menambahkan variabel independen yang lain seperti asimetri informasi dan menambahkan variabel kepemilikan manajerial dalam proksi Corporate Governance.

4) Sebelum melakukan penelitian, sebaiknya peneliti memastikan ketersediaan data agar tidak menemui kendala ketika melakukan penelitian.

\section{DAFTAR PUSTAKA}

Almadara, H. U. (2017). Pengaruh Leverage Terhadap Manajemen Laba dengan Corporate Governance Sebagai Variabel Moderasi Pada Perusahaan Perbankan yang Terdaftar Di BEI. SKRIPSI.

Asy'ari, E. F. (2016). Pengaruh Leverage, Free Cash Flow Terhadap Manajemen Laba dengan Corporate Governance Sebagai Variabel Pemoderasi. SKRIPSI.

Badruzzaman, N. (2010). Earnings Management. Modul Ajar Universitas Widyatama.

Boediono, G. (2005). Kualitas Laba: Studi Pengaruh Mekanisme Corporate Governance dan Dampak Manajemen Laba dengan Menggunakan Analisis Jalur.
Simposium Nasional Akuntansi (SNA) VIII Solo.

Christiani, I., \& Nugrahanti, Y. W. (2014). Pengaruh Kualitas Audit Terhadap Manajemen Laba. Jurnal Akuntansi dan Keuangan, Vol. 16, No. 1.

Firth, M., \& Smith, A. (1992). The Accuracy of Profits Forecasts in Initial Public Offering Prospectuses. Accounting and Business Research Vol.22, No.87, 239-247.

Guna, W. I., \& Herawaty, A. (2010). Pengaruh Mekanisme Good Corporate Governance, Independensi Auditor, Kualitas Audit Dan Faktor Lainnya Terhadap Manajemen Laba. Jurnal Bisnis dan Akuntansi, Vol. 12 No. 1, 53-68.

Herawaty, V. (2008). Peran Praktek Corporate Governance Sebagai Moderating Variable dari Pengaruh Earnings Management Terhadap Nilai Perusahaan. Jurnal Akuntansi dan Keuangan, Vol.10, No.2, 97108.

Jensen, M. C., \& Meckling, W. H. (1976). Theory of The Firm: Managerial Behavior, Agency Cost and Ownership Structure. Journal of Financial Economics. Vol.3, 305360.

Juniarta, I. W., \& Sujana, I. K. (2015). Pengaruh Financial Leverage Pada Income Smoothing Dengan Good Corporate Governance Sebagai Variabel Pemoderasi. E-Jurnal Akuntansi Universitas Udayana 11.3, 921-939.

Luhgiatno. (2010). Analisis Pengaruh Kualitas Audit Terhadap Manajemen Laba. Jurnal Akuntansi Riset, Prodi Akuntansi UPI, Vo.2, No.1.

Mahiswari, R., \& Nugroho, P. I. (2014). Pengaruh Mekanisme Corporate 
Governance, Ukuran Perusahaan dan Leverage Terhadap Manajemen Laba dan Kinerja Keuangan. Jurnal Ekonomi dan Bisnis.

Midiastuty, P. P., \& Machfoedz, M. (2003). Analisis Hubungan Mekanisme Corporate Governance Dan Indikasi Manajemen Laba. Simposium Nasional Akuntansi VI.

Naftalia, V. C. (2013). Pengaruh Leverage Terhadap Manajemen Laba Dengan Corporate Governance Sebagai Variabel Pemoderasi. Diponegoro Journal Of Accounting, 1-8.

Perdana, R. (2012). Pengaruh Firm Size, Leverage, Good Corporate Governance, dan Profitabilitas Terhadap Earning Management. Skripsi.

Porter, G. (1992). Accounting Earnings Announcemnt, Institutional Investors Concentration and Common Stock Returns. Journal of Accounting Research Vol.30, No.1, 146-155.

Rahmawati, H. I. (2013). Pengaruh Mekanisme Good Corporate Governance (Gcg) Terhadap Manajemen Laba Pada Perusahaan Perbankan yang Terdaftar di Bursa Efek Indonesia Tahun 2009-2011. Skripsi.

Richardson, V. J. (1998). Information Asymmetry an Earnings Management: Some Evidence. Dissertation, University of Kansas.

Riyanto, B. (1995). Dasar-Dasar Pembelanjaan Perusahaan. Yogyakarta: BPFE-Yogyakarta.

Sartono, A. (2014). Manajemen Keuangan Teori dan Aplikasi. Edisi Keempat. Yogyakarta: BPFE.
Setiawati, L. (2002). Manajemen Laba dan IPO di Bursa Efek Jakarta. Simposium Nasional Akuntansi 5.

Siregar, S. V., \& Utama, S. (2005). Pengaruh Struktur Kepemilikan, Ukuran Perusahaan, dan Praktek Corporate Governance Terhadap Pengelolaan Laba (Earnings Management). SNA VIII Solo.

Sugiyono. (2016). Metode Penelitian Kuantitatif Kualitatif $R \& D$. Bandung: Alfabeta. 